\title{
LABOR LAW: READING PROVISION IN NLRB ORDER IS INAPPROPRIATE EXCEPT IN EXTREME CASES
}

Requiring an employer to read an NLRB order to his employees has been held by the Court of Appeals for the District of Columbia Circuit, in International Union of Electrical Workers v. NLRB,1 to be an inappropriate remedy and one which will be enforced only in extreme cases. Four months after initiating an organizational campaign among employees of Scott's, Inc., the IUE filed unfair labor practice charges with the NLRB. The trial examiner and the Board found that the company had deliberately engaged in extensive violations of sections 8(a) (1) to (3) of the National Labor Relations Act. $^{2}$ Among other remedies, the NLRB directed the company to post on plant bulletin boards notices stating the employer's intention to remedy past unfair practices and to respect enumerated employee rights, to mail a copy to each employee at his home, and to read the notice to assembled employees during working hours. ${ }^{3}$ Upon petition by the union for review, and by the NLRB for enforcement, the District of Columbia Circuit affirmed the Board's findings and orders, except for the requirement of the oral reading of the employee notice. ${ }^{k}$

The National Labor Relations Board has wide latitude in issuing orders and formulating remedies; the National Labor Relations Act specifies only that orders and remedies must effectuate its policies. ${ }^{5}$ This requirement has been interpreted to mean that the orders of the Board are to be corrective rather than punitive, ${ }^{b}$ and must be designed to restore the status quo by counteracting the detrimental effects of an unfair labor practice. ${ }^{7}$ Because the relationship of policy

1383 F.2d 230 (D.C. Gir. 1967), petition for cert. filed, 36 U.S.L.W. 3243 (U.S. Dec. 12, 1967) (No. 878), modifying Scott's, Inc., 159 N.L.R.B. No. 146 (June 30, 1966). 229 U.S.C. $\$ \S 158$ (a) (1)- (3) (1964).

${ }^{3}$ Scott's, Inc., 159 N.L.R.B. No. 146 (June 30, 1966).

383 F.2d 230 (D.C. Cir. 1967), petition for cert. filed, 36 U.S.L.W. 3243 (U.S. Dec. 12, 1967) (No. 878).

National Labor Relations Act $\$ 10$ (c), 29 U.S.C. $\$ 160$ (c) (1964).

- Republic Steel Corp. v. NLRB, 311 U.S. 7, $11-12$ (1940); Consolidated Edison Co. v. NLRB, 305 U.S. 197, 235-36 (1938); Marshfield Steel Co. v. NLRB, 324 F.2d 333, 33738 (8th Cir. 1963); Nabors v. NLRB, 323 F.2d 686, 690 (5th Cir. 1963), cert. denied, 376 U.S. 911 (1964); NLRB v. Teamsters Local 996, 313 F.2d 655, 660 (9th Cir. 1963). ${ }^{7}$ Fibreboard Paper Prods. Corp. v. NLRB, 379 U.S. 203, 216 (1964); Phelps Dodge Corp. v. NLRB, 313 U.S. 177, 194 (1941); Ladies' Garment Workers' Local 57 v. NLRB, 374 F.2d 295, 300 (D.C. Cir.), cert. denied, 387 U.S. 942 (1967). 
to remedy is considered a matter peculiarly within administrative competence, the Board's remedial power is subject to limited judicial review. ${ }^{8}$ Thus, an order should be affirmed, the Supreme Court has held, unless it is found to be a patent attempt to achieve a result not implementing the policies of the Act. ${ }^{9}$

A conclusion by the Board that an employer has committed an unfair labor practice will usually result in an order that the employer post a signed notice to the effect that, in accordance with the decision of the NLRB, the employer will take certain remedial actions and will not engage in specified unfair labor practices. Prior to the IUE case, the NLRB on several occasions has required employers to read this notice to the employees. ${ }^{10}$. The Fourth Circuit has enforced the reading provision without discussion of its propriety.11 A similar remedy was approved by the Second Circuit in J.P. Stevens \& Company v. $N L R B,{ }^{12}$ with the modification that the company be given the option of having the notice read by a Board representative. The Stevens court, accepting the Board's reasoning that the reading would insure effective communication to employees of the Board's order, noted that the humiliating aspects of the public reading were lessened by the modification and by the omission from the notice of an admission of past offenses. ${ }^{13}$ In NLRB v. Laney \& Duke Storage Warehouse Company, ${ }^{14}$ a Board order requiring an employer to read a notice to its employees was rejected by the Fifth Circuit although it had enforced a similar provision in an earlier case. ${ }^{15}$ The trial

\footnotetext{
${ }^{8}$ National Labor Relations Act $\$ 10$ (e), 29 U.S.C. $\$ 160$ (e) (1964); see NLRB v. Seven-Up Bottling Co., 344 U.S. 344 (1953); Phelps Dodge Corp. v. NLRB, 313 U.S. 177 (1941).

- Fibreboard Paper Prods. Corp. v. NLRB, 379 U.S. 203, 215-16 (1964); Virginia Elec. \& Power Co. v. NLRB, 319 U.S. 533, 540 (1943).

${ }^{20}$ J.P. Stevens \& Co., 157 N.L.R.B. 869, 879 (1966), modified, 380 F.2d 292 (2d Gir.), cert. denied, 389 U.S. 1005 (1967); Laney \& Duke Storage Warehouse Co., 151 N.L.R.B. 248, 249 (1965), modified, 369 F.2d 859 (5th Cir. 1966); Great Atl. \& Pac. Tea Co., 134 N.L.R.B. 458, 459 (1961); Jackson Tile Mfg. Co., 122 N.L.R.B. 764, 770 (1958), enforced per curiam, 272 F.2d 181 (5th Cir. 1959); cf. Taylor-Colquitt Co., 47 N.L.R.B. 225, 257, enforced, 140 F.2d 92 (4th Cir. 1943).

${ }^{21}$ NLRB v. Taylor-Colquitt Co., 140 F.2d 92 (4th Cir.), enforcing 47 N.L.R.B. 225 (1943).

12380 F.2d 292 (2d Cir.), cert. denied, 389 U.S. 1005 (1967), modifying 157 N.L.R.B. 869 (1966).

${ }^{18} \mathrm{Id}$. at $304-05$.

14369 F.2d 859 (5th Cir. 1966), modifying 151 N.L.R.B. 248 (1965).

${ }^{25}$ Jackson Tile Mfg. Co. v. NLRB, 272 F.2d 181 (5th Cir. 1959), enforcing per curiam 122 N.L.R.B. 764 (1958).
} 
examiner's recommended order-which because of employee illiteracy had compelled a reading to any employee requesting it $^{16}$-was modified by the Board to require the employer to read the notice once to each employee, singly or collectively. ${ }^{17}$ Disregarding the employee illiteracy, the Fifth Circuit summarily concluded that the reading provision was "unnecessarily embarrassing and humiliating to management ...." and would not work to promote the policies of the Act. ${ }^{18}$

In concluding in $I U E$ that the prescribed reading was an inappropriate means of informing employees of their rights under the Act, the District of Columbia Circuit stated that the oral reading would impair future labor relations by further alienating employers and union members, and agreed with the Laney of Duke Storage court that such action was unnecessarily humiliating to management. ${ }^{19}$ Conceding that such a remedy might possibly be justified by extreme actions on the part of an employer or union, the court concluded that in the usual case a forced public reading amounted to a " confession of sins' . . . incompatible with the democratic principles of the dignity of man."20 Judge Wright, dissenting in part, argued that the remedies prescribed did not meet the criterion established by the Supreme Court for judicial rejection of an NLRB order. ${ }^{21}$ He further contended that any complication created by the order could be eliminated by enforcement with the modification adopted in Stevens. The majority rejected the Stevens modification with the assertion that such an alteration would amount to a new order, and thus would exceed the court's authority. In addition, the majority found the Stevens change substantively unacceptable because it promoted the Board's participation in a controversy from which it should remain neutral, and would destroy the laboratory conditions necessary for any future election. ${ }^{22}$

The specific facts of $I U E$ reveal sound reasons for enforcement of the Board's reading order. The vice-president of the company had assembled employees and verbalized the company's policy of

\footnotetext{
10 151 N.L.R.B. at 267.

${ }^{17} \mathrm{Id}$. at 249 .

18369 F.2d at 869 .

10383 F.2d at $233-34$.

20 Id. at 234.

${ }^{2 x}$ Id.

${ }^{2}$ Id. at n.5.
} 
opposition to unionization, outlining actions taken by the company in other subsidiaries. ${ }^{23}$ Unlike a posting or mailing which might be disregarded by employees, a public reading would ensure that the compliance notice was communicated to all who heard the company's threats. Further, in evaluating the reading provision, the IUE court inquired whether the remedy chosen by the NLRB was "inappropriate to achieve the sought-after goal of dissemination of information concerning employees' rights." ${ }^{24}$ This standard arguably allows greater judicial latitude for rejection than does the criterion established by the Supreme Court, i.e., whether the remedy is "a patent attempt to achieve ends other than those which can fairly be said to effectuate the policies of the Act." ${ }^{25}$

Any humiliating aspects of the reading provision do appear to be avoided by the Stevens modification. Furthermore, since Judge Wright's proposal would involve a non-factual amendment, the literal language of the Act allowing court "modification" of NLRB orders $^{26}$ does not appear to require the conclusion that altering the order to provide an optional Board reading was beyond the court's power. Though the legislative history of the NLRA does not discuss the extent of the courts' modification powers when non-factual determinations are involved, ${ }^{27}$ alterations of the same nature as that in Stevens have been undertaken by other courts but without an analysis of the authorization to do so. ${ }^{28}$ The IUE court's further criticism that the Stevens alteration would involve the Board too deeply in the controversy is weakened by the Board's prior, well-known in. volvement in the case.

The reading provision ordered in IUE is a relatively novel NLRB remedy and, as one commentator has suggested on the basis of an extensive empirical study of unfair labor cases, may be of

${ }^{28} 159$ N.L.R.B. No. 146, at 5-6 (June 30, 1966).

26383 F.2d at 232-33.

${ }_{25}$ Virginia Elec. \& Power Co. v. NLRB, 319 U.S. 533, 540 (1943). See note 10 supra.

${ }^{26}$ National Labor Relations Act $\$ 10$ (e), 29 U.S.C. $\$ 160$ (e) (1964).

at See NLRB, Legislative History of the National Labor Relations AGt, 1935 (1949); NLRB, Legislative History of the Labor MLANagement Relations Act, 1947 (1948).

${ }_{28}$ See NLRB v. Operating Eng'rs Local 138, 293 F.2d 187, 199 (2d Cir. 1961), modifying 123 N.L.R.B. 1393 (1959) (modification to make union primarily liable and employer secondarily liable); NLRB v. Hollywood-Maxwell Co., 126 F.2d 815, 819 (9th Gir. 1942), modifying 24 N.L.R.B. 645 (1940) (modification to include description of employer's dishonesty and requiring Board's notice to be posted). 
significant remedial value in some contexts. ${ }^{29}$ When employees are illiterate or transient, an oral reading may be the only effective method of informing them of their NLRA rights. Unless the court would view these as "extreme cases," the IUE decision tends to restrict the NLRB by stifling the creativity required for effective remedy formulation in such situations..$^{30}$

${ }^{30}$ Ross, Analysis of Administrative Process Under Taft Hartley, 63 LAB. REL. REP. 132, 153 (1966).

${ }^{30}$ See Note, The Need for Creative Orders Under Section 10(c) of the National Labor Relations Act, 112 U. PA. L. REv. 69 (1963). 